\title{
Positive youth development merits state investment
}

by David Campbell, Kali Trzesniewski, Keith C. Nathaniel, Richard P. Enfield and Nancy Erbstein

In the last three decades, positive youth development has emerged as the new paradigm for youth-related research and programming. The literature provides strong evidence that high-quality youth programs can have positive and significant effects. Positive youth development is strongly associated with three outcomes of particular public significance: improved school achievement and graduation rates, decreased incidence of risk behaviors and increased sense of personal efficacy and empathy. A strong economic case could be built for increasing public investment in positive youth development programs. What is needed now is more and better data, and measurable goals at the state level.

$\mathrm{R}_{\mathrm{b}}^{\mathrm{e}}$ esearch over the last 30 years has borne out the value of positive youth development (PYD), resulting in a major shift in youth development research (Lerner and Benson 2003). Before this shift, researchers, scholars and practitioners developed youth-serving programs and institutions mainly on a deficit model: They considered high-risk youth behaviors and problems to be the focus of their work (Lerner et al. 2011). Youth were problems to be managed, and this mind-set generated strategies oriented toward intervening after the fact rather than prevention. In today's research environment, however, youth are increasingly considered community assets to be developed and nurtured (Damon 2004; Irby et al. 2001).

Research suggests that far too many California youth are not thriving. Approximately one out of six 16- to 24-year-olds in California is out of school and out of work (Benner et al. 2010; Lamming et al. 2006; Sum 2003). Each year, about 100,000 California youth reach graduating age but do not graduate from high school (Taylor and Rumberger 2010). These youth have a higher unemployment

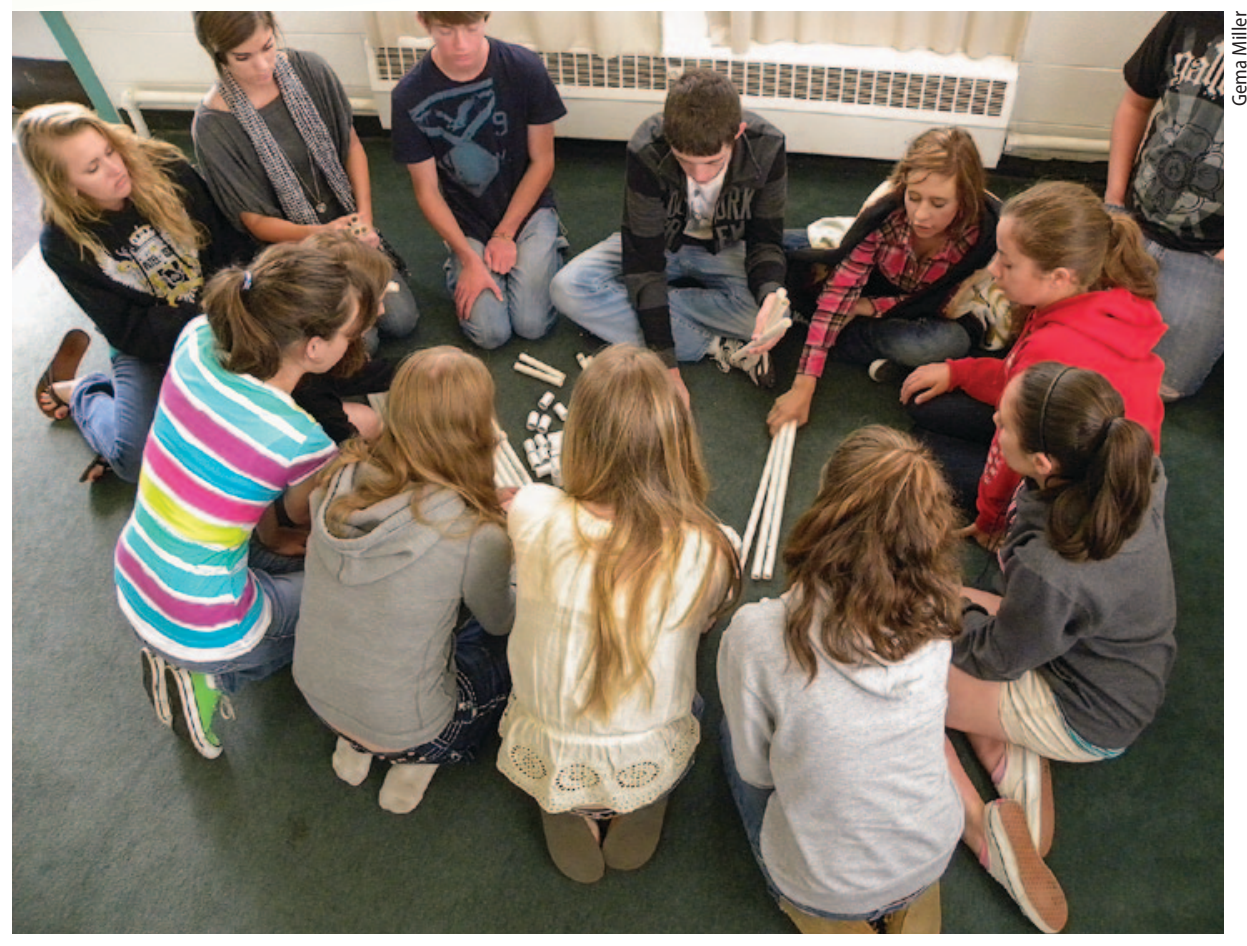

Researchers increasingly view young people as community assets to be nurtured, rather than focusing on high-risk youth behaviors and interventions after the fact. Above, 4-H state ambassadors at Point Bonita orientation build their competence and connection skills through group problem solving.

rate, lower lifetime earnings and a greater likelihood to be the target of public expenditures for health, welfare and criminal justice services (London and Erbstein 2011). Promotion of healthy pathways to college, work and community engagement is of urgent concern, not only for the youth and their immediate families and communities but for California as it seeks to replace an aging workforce, sustain a vibrant democracy and remain competitive in the global economy.

\section{What is positive youth development?}

Drawing on the work of Hamilton (1999), Lerner et al. (2011) describe a threepart conception of PYD as a developmental process, a philosophy or approach to youth programming, and situations in which youth programs and youthserving organizations foster the healthy development of youth. Here we identify the characteristics held in common by positive youth development programs that are effective in helping youth develop competence in many areas of life, including social connections (i.e., access to people, institutions and networks), personal character, confidence and the ability to care and to contribute to society (Gomez and Ang 2007). Although they are critically important, strategies to support these programs via systems change within schools, juvenile justice, healthcare and social welfare institutions are beyond the scope of this review (Pittman 1991, 2000).

\section{Guiding frameworks and principles}

Scholars have used a number of research-derived youth development frameworks to describe the needs of youth and guide the development of PYD programs. As summarized by Heck and Subramaniam (2009), these frameworks include the assets model of the Search Institute (Benson et al. 2006; Oman et al. 2002; Theokas et al. 2005), the four essential elements framework promoted by the national and state $4-\mathrm{H}$ Youth Development Program (Kress 2003;

Online: http://californiaagriculture.ucanr.edu/ landingpage.cfm?article $=$ ca.v067n01p38\&fulltext=yes DOI: 10.3733/ca.v067n01p38 
Peterson et al. 2001), the five (sometimes six) C's of positive youth development (Lerner 1995; Lerner et al. 2000; Pittman et al. 2000; Roth and Brooks-Gunn 2003) and the Thrive framework (Heck et al. 2010;

Thrive Foundation for Youth 2010). While these frameworks have some notable differences, both in their terminology and in the extensiveness of their lists of critical youth competencies, they have much in common. Heck and Subramaniam (2009,

21) identify six key developmental competencies common to them all.

Mastery and competence. All of the PYD frameworks emphasize skill building, with a shared focus on skills for learning and academic success and skills relevant to crafts, arts, sports, work, management of emotions, and building and sustaining relationships. Through success in developing personal skills, youth increase their confidence and establish a foundation for developing other competencies. For example, the 35 life skills promoted in 4-H programs have been used to develop successful initiatives and as a framework for evaluations of other youth programs (Heck and Subramaniam 2009; Hendricks 1996). Taylor-Powell and Calvert (2006) found that the 4-H Arts and Communication program in Wisconsin improved participating youth's general sense of competence.

Independence and confidence. Youth need to be able to differentiate themselves from others, and they need the confidence to exercise that independence in a variety of settings and situations, including those that are complex or difficult. Confidence indicates self-esteem and positive identity (Roth and Brooks-Gunn 2003) as well as resiliency (Benard 1991, 1993, 2004).

Benard $(1993,44)$ notes that resilient youth have "the ability to bounce back successfully despite exposure to severe risks." Her research links this capacity to certain attributes that allow youth to overcome adversity and stress. These attributes include social competence, problem-solving skills, autonomy and a sense of purpose and future. Resilient children tend to be good learners and good problem solvers (Masten et al. 1990).

Generosity, caring and compassion. The PYD frameworks stress the need to nurture character and a strong sense of personal values, which lead to empathy and caring for others. The frameworks recognize that individual development cannot be divorced from the relationships, social contexts and public settings in which young people find themselves. In a survey of 6,000 youth, grades 6 through 12 , Scales et al. (2000) found "helping others" to be strongly related to the presence of developmental assets as identified in the Search Institute framework, particularly time spent in one's religious community and time spent in youth programs. Phelps et al. (2009) validated caring (defined as feeling sorry for the sadness of others) as a key developmental asset.

Initiative and purpose. Healthy youth have an increased capacity to initiate work and to act on the world. They can sustain self-motivation as they direct their attention and action toward achievement of a challenging goal (Larson $2000,170)$. With a sense of purpose, youth are possessed of a deep reason, a sense of inspiration or meaning that motivates them to learn and achieve. Research shows that youth with a sense of purpose have more-positive developmental outcomes (Damon 2004). One source of purpose can be spiritual growth. Shaped both within and outside of religious traditions, spiritual growth is often an important driver in the search for meaning in life (Benson et al. 2003). Another source of purpose highlighted by researchers and practitioners of social justice youth development is the desire to improve conditions for one's family and community (Ginwright and James 2002).

Involvement and contribution. Youth need meaningful ways to contribute within their home, school, organizations and civic institutions. Surveys of youth participating in PYD programs characterize their ability to contribute as highly significant (Alberts et al. 2006). As Campbell and Erbstein (2012) note:

... engagement can deepen civic commitment, extend social capital, create meaningful relationships with adults, foster self-esteem and identity development, and build a sense of self and collective efficacy (Hughes and Curnan 2000; Irby et al. 2001; Gambone et al. 2006).

Ginwright and Cammarota $(2007,694)$ highlight the transformative power of a "critical civic praxis," a strategy for putting social theory into practice. It can give our most marginalized youth populations access to the networks, ideas and experiences that build individual and collective capacity to foster equitable opportunities and outcomes.

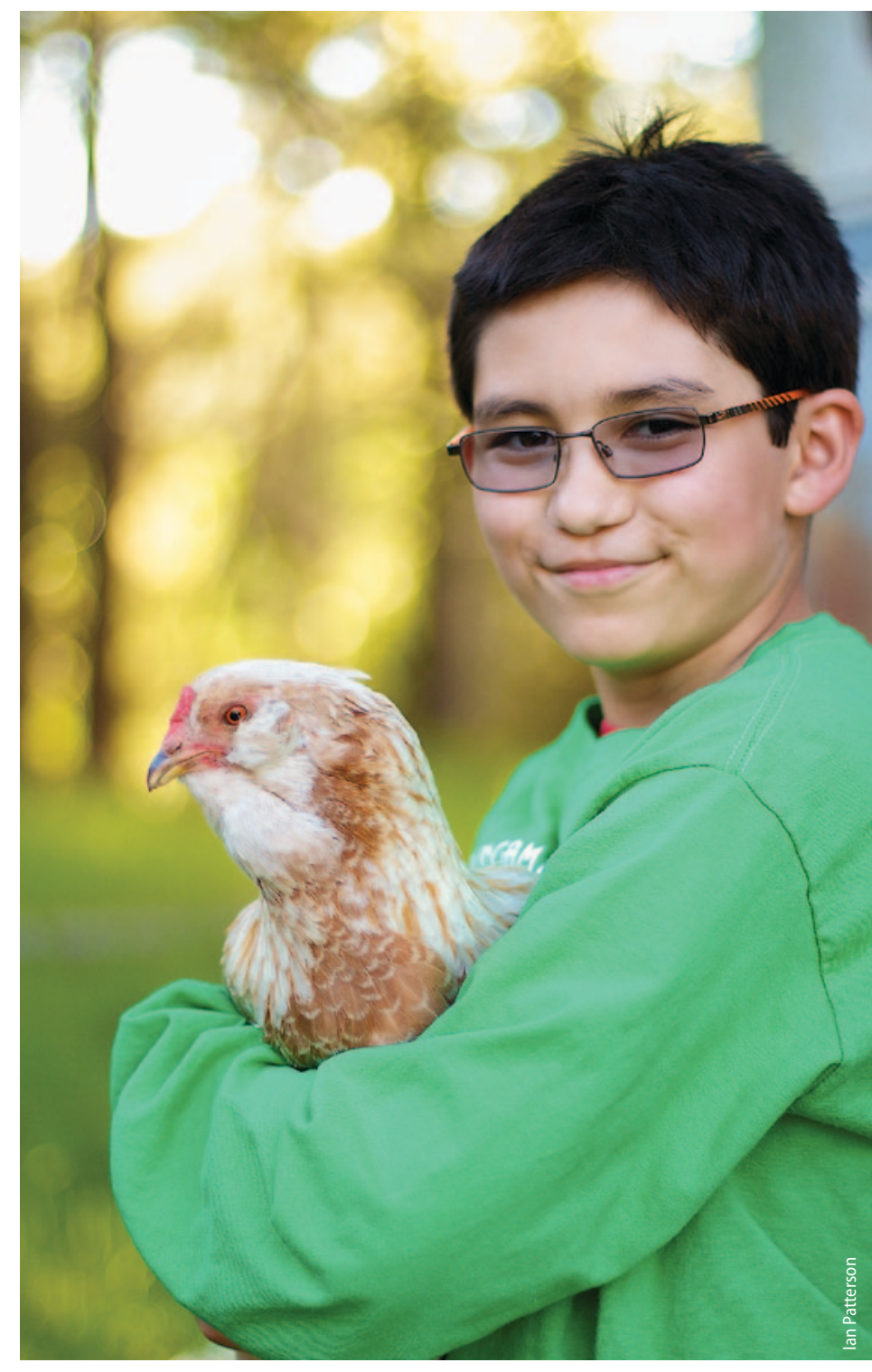

Through animal science projects, 4-H members gain a greater sense of purpose, which leads to improved contributions to their communities. Above, a 4-H member at a spring exposition, San Mateo County fairgrounds. 
Belonging and connections. All of the frameworks discussed here point to the importance of positive, supportive relationships with peers and adults, whether family members, teachers, mentors or other adults. Supportive relationships help create a sense of appropriate boundaries and expectations while enhancing feelings of personal safety and development of a positive identity. Programs and activities that support social skill acquisition and relationship building can result in improvements in both academic achievement and self-perception (Durlak et al. 2007).

Hensley et al. (2007) found that with increased involvement in 4- $\mathrm{H}$, a youth's sense of belonging increased. As Russell and Van Campen (2011) argue, many mainstream youth programs such as the Boy Scouts and YMCA do a much better job of providing connections for middleclass youth, traditional families and dominant cultural groups than they do

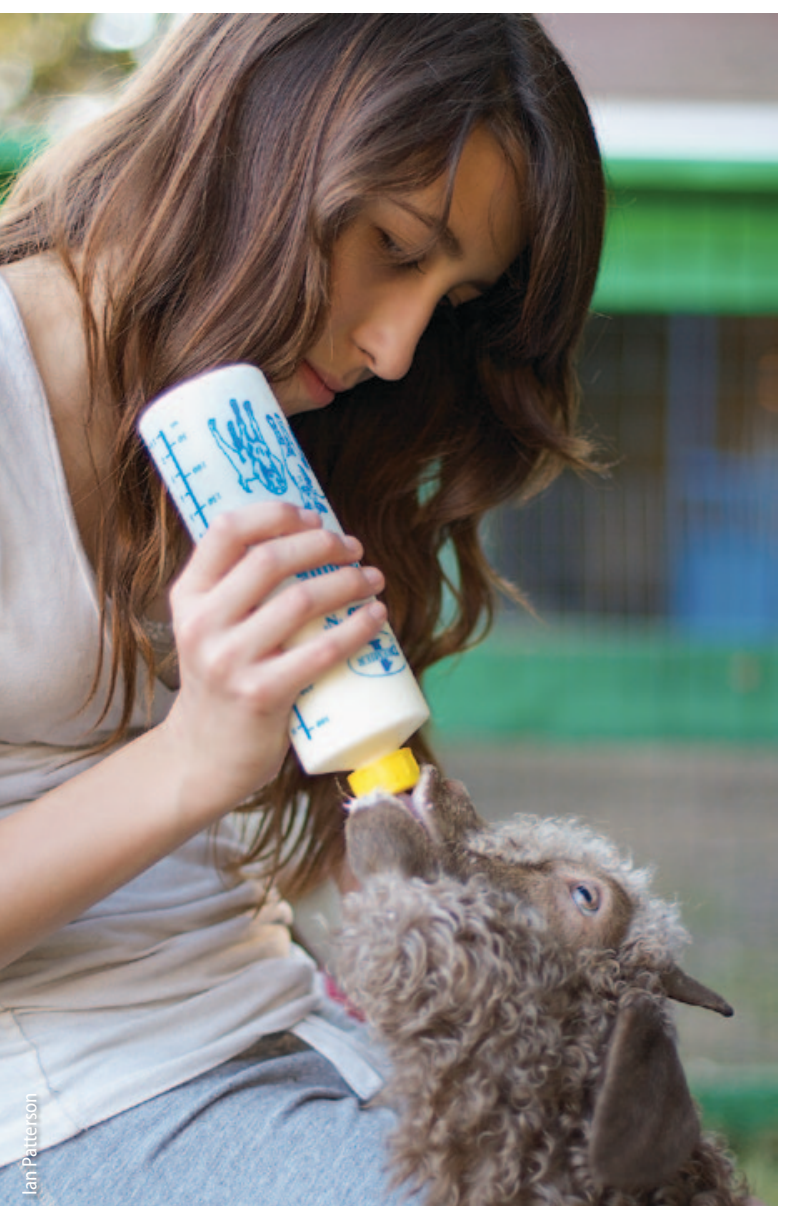

As 4-H members become more competent and confident working with their animals, they are introduced to basic practices in veterinary medicine. in reaching more marginal populations such as immigrant youth, young people growing up in low-income households or lesbian, gay, bisexual or transgender (LGBT) youth.

One strategy to increase belonging and connection for a greater diversity of young people is to build upon ethnic and cultural networks, youth culture and knowledge within communities (Burciaga and Erbstein 2010; Yosso 2005). For example, drawing on the Chicana/ Chicano tradition of community art workshops (Jackson 2009), the Department of Chicana/o Studies at UC Davis has collaborated with the Yolo County Housing Authority to launch Taller Arte del Nuevo Amanecer (TANA). This studio engages youth living in nearby subsidized housing and beyond, documenting their experience and hopes through silk-screen printing and mural painting, providing access to new skills and a safe space for community building. (See http:// ucdavismagazine.ucdavis.edu/issues/ su10/drawing_on_culture.html.)

\section{PYD program results}

There are many types of youth-serving entities that offer PYD programs, including government agencies, universities and schools, nonprofit organizations, faithrelated institutions and ethnic networks. Backed with public funding and operating through the auspices of land-grant universities, the 4-H Youth Development Program is among the most long-standing of them. It creates a safe environment where adults and youth can work together on meaningful, inquiry-based learning. Another example is the nonprofit Boys and Girls Clubs of America, which solicits grants and donations to further its mission of providing a safe place for youth to learn, grow and experience ongoing relationships with caring adult professionals.

Thousands of churches and faithrelated nonprofits across the nation offer youth programs such as tutoring, spiritual exploration, camping, crafts, career exploration and community service. Still other programs engage youth in exploring and celebrating their cultural identity or defining community challenges and getting organized to create meaningful community change (Campbell and Erbstein 2012).

Study approach. Our first question was whether these PYD programs result

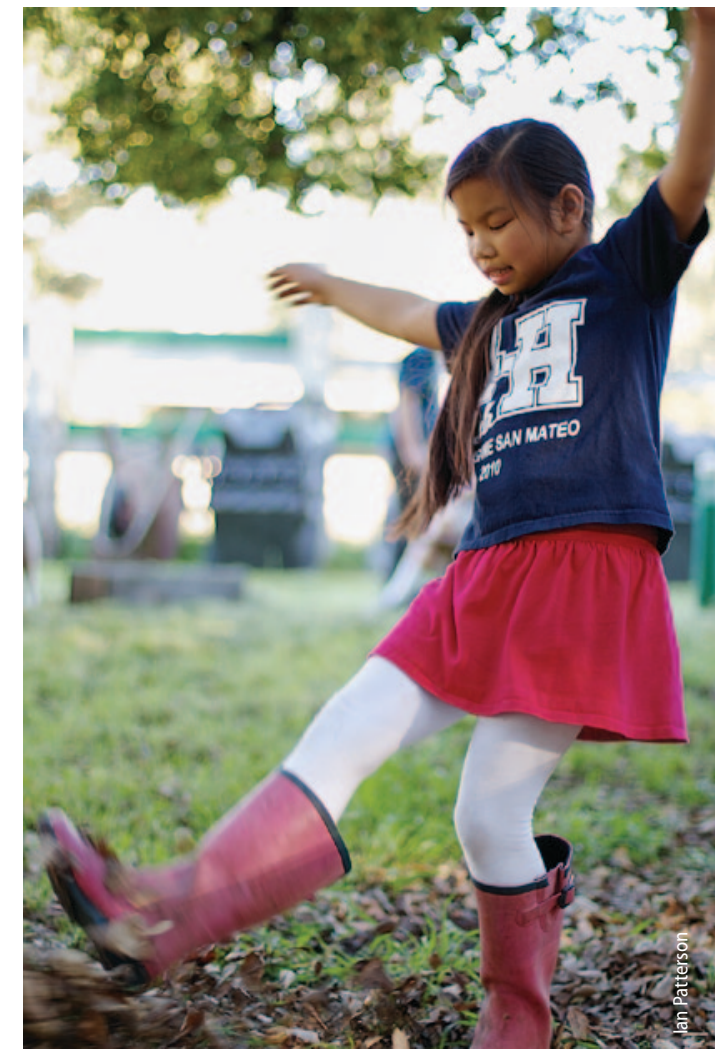

After-school programs that promote personal and social skills result in improved test scores and grades - even more than programs focusing on academics alone. 4-H helps young people discover the things that give them joy, energy and passion for making the world a better place.

in positive outcomes for youth. For this analysis, we reviewed a wide variety of peer-reviewed publications from the past two decades that used formal evaluation data to track the effects of PYD programs. Within this growing body of literature, we paid particular attention to metareviews that synthesized the findings of previous studies and to individual longitudinal studies with large sample sizes.

Because this article aims to provide a concise literature review that identifies promising policy and program directions, we will not provide a detailed accounting of the methodological strengths and limits of individual studies. However, several general caveats regarding the literature should be noted. While many studies provide evidence of a relationship between PYD programs and beneficial youth outcomes, this relationship is not present in all cases. When such effects are found, they range widely in magnitude across different studies. The relationships discussed are stronger in high-quality 
programs. (We discuss what constitutes a high-quality program below.)

Overall, the findings tend to reflect correlational rather than causal relationships. Many studies do not control for selfselection into programs or exposure to PYD support in families and communities, and that makes it difficult to distinguish the outcomes that flow from informal efforts by parents, peers and communities from outcomes that can be created in structured youth programs. Also, many PYD programs have not been formally evaluated, and existing evaluations often have not disaggregated youth experience by demographic, cultural and geographic characteristics to assess whether the outcomes are consistent across different populations and places.

Despite these caveats, there is strong evidence that high-quality youth programs can have positive and significant effects. Support for PYD in a young person's life is positively associated with three outcomes of particular public significance:

- Improved school achievement and graduation rates.

- Decreased incidence of risk behaviors.

- Increased sense of personal efficacy and empathy.

Improved school achievement, graduation. Research shows a strong correlation between involvement in PYD programs and improved academic achievement (Gomez and Ang 2007; Guest and Sneider 2003). Indeed, Meltzer et al. (2006) found that the length of time spent in PYD programs during childhood and adolescence predicted positive outcomes during adulthood, including increased high school graduation rates and improved college attendance.

A qualitative review of 161 PYD programs found that school achievement and attachment were improved among participants (Catalano et al. 2004). Also, strong evidence from a recent meta-analysis of studies that employed experimental designs indicates that participation in afterschool programs that promote personal and social skills has resulted in increased achievement test scores, grades, school attendance and school bonding, when compared to control conditions (Durlak et al. 2010). Impressively, the overall increase in achievement gained by participating in these social-emotional learning programs was larger than is typically found for programs that focus only on academics.

Decreased incidence of risk behaviors. Many researchers have found correlations between PYD and the prevention of self-destructive behaviors (Beets et al. 2009; Benson 1997; Benson and Pittman 2001; Benson and Scales 2009; Benson et al. 1998; Benson et al. 2006; Catalano et al. 2004; Goldschmidt et al. 2007; Hawkins et al. 2009; Oman et al. 2002; Tebes et al. 2007; Weissberg and Utne O'Brien 2004). A formal meta-analysis of rigorous evaluations found that after-school programs promoting personal and social skills were effective in reducing problem behaviors and drug use (Durlak et al. 2010). Other research has linked PYD to a reduction in potentially dangerous sexual activity, including early or frequent sexual intercourse, multiple sexual partners, not using birth control and failing to protect against sexually transmitted diseases (Catalano et al. 2004; Gavin et al. 2009; Gloppen et al. 2010; Sieving et al. 2011; Weissberg and Utne O’Brien 2004).

Increased efficacy and empathy. Multiple studies have found that PYD programs promote positive personal traits and relationships, built on both self-assertive and self-regulative efficacy and empathy (Anderson et al. 2007; Catalano et al. 2004; Roth and Brooks-Gunn 2003). Higher levels of key PYD indicators predict greater contributions to family and community (Lerner et al. 2008). And metaanalytic findings show that after-school programs promoting personal and social skills improved self-esteem and self-efficacy and increased positive interactions with others (Durlak et al. 2010).

\section{High-quality programs}

The achievement of these outcomes across a wide range of programmatic settings is indicative of the payoffs the public might expect from high-quality PYD programs. However, the degree to which these outcomes may be evident in any given program or community setting appears to depend on program quality. To bring about the desired outcomes for youth, a program must embody specific key characteristics.

Characteristics. The most exhaustive review of the literature on this topic remains the National Research Council's report of the Committee on CommunityLevel Programs for Youth (NRC/IOM 2002). The authors identified eight characteristics of positive developmental settings (see pp. 9-10 of report): physical and psychological safety, appropriate structure, supportive relationships, opportunities to belong, positive social norms,

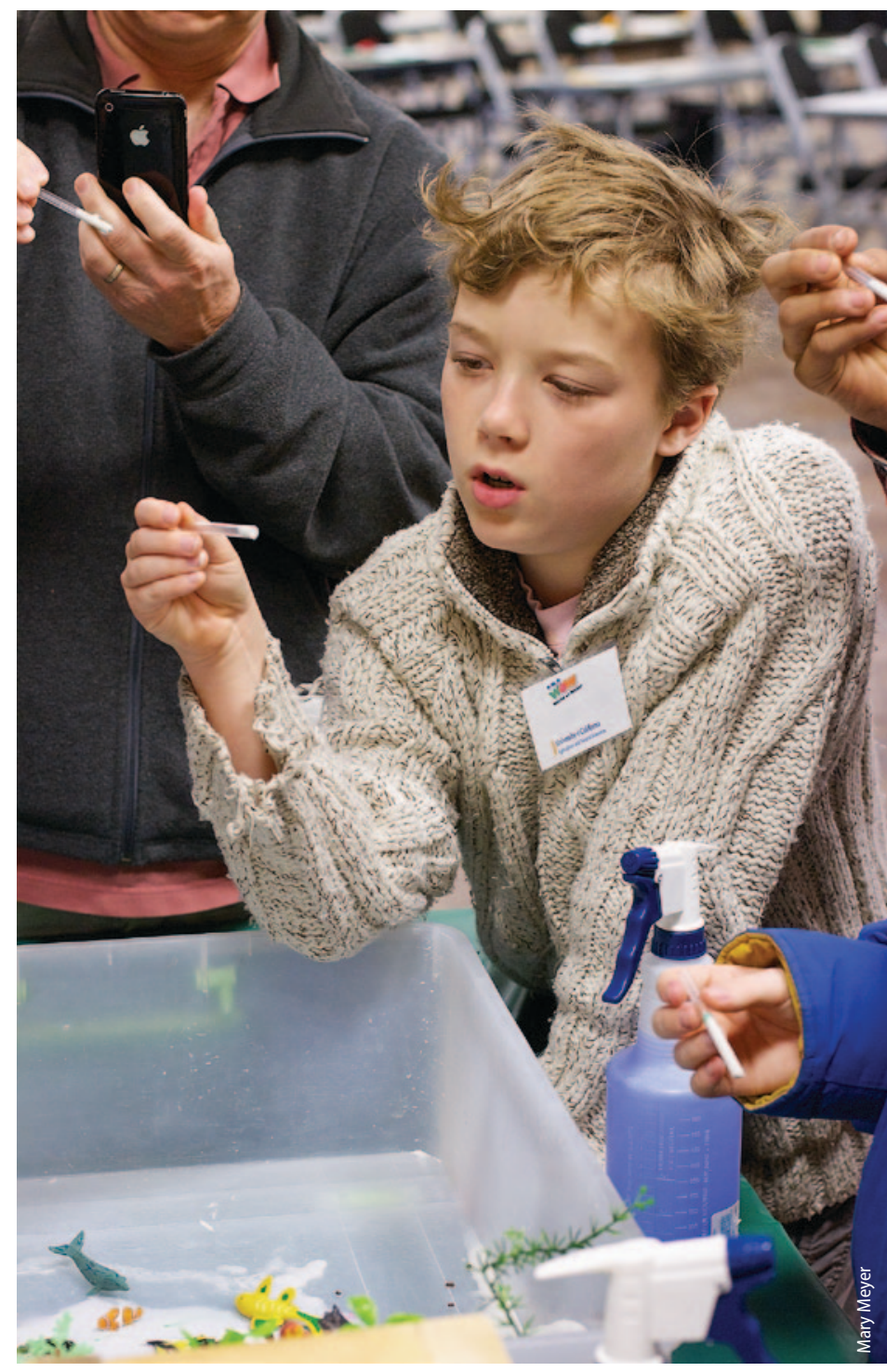

Scientific inquiry is a primary educational practice in 4-H, which builds youth competence and love of learning. Above, participants in a National Youth Science Day activity at San Mateo County's 4-H World of Water workshop. 
programs that attend to cultural and organizational factors that might be limiting the participation of underrepresented populations (Erbstein 2010; Romero et al. 2010; Russell and Van Campen 2011).

An example of a project that addresses the circumstances of disadvantaged youth is an effort funded by UC Agriculture and Natural Resources (ANR) to extend indices of youth well-being and vulnerability in California (see sidebar below). The aim is to produce accurate, compelling and actionable data at the community scale, by targeting resources to neighborhoods or subpopulations that have a particular need for support.

\section{Costs and benefits}

We also need better data to assess the costs and benefits of investing in PYD programs. The available data suggests that the economic rationale is potentially strong, but more supporting evidence is needed. Some progress is being made in developing this data. One strand of research documents the costs of running high-quality youth programs (Grossman et al. 2009), so that policymakers can estimate the scope of investment required. Another strand estimates the costs to society of failure to make sufficient youth investments.

Using estimates developed by Belfield and Levin (2007a, 2007b), researchers at UC Davis calculated that the approximately 9,000 students in the nine-county Sacramento capitol region who leave high school without graduating each year represent a combined loss of nearly \$215 million in wages and purchasing power, while adding $\$ 480$ million to state and local tax burdens for services and more than $\$ 1$ billion to the federal budget for services (Benner et al. 2010; London and Erbstein 2011). Likewise, teen births are not only associated with a higher likelihood of becoming a high school dropout, they also directly impact public expenditures: "In the United States, the annual cost of teen pregnancies from lost tax revenues, public assistance, child health care, foster care, and involvement with the criminal justice system was estimated to be $\$ 9.1$ billion in 2004" (Geraghty 2010).

Substance abuse rates also impact public expenditures both directly and by reducing graduation rates. Currently, California faces a crisis, with more youth and adults in need of substance abuse treatment than there are available facilities (Geraghty 2010, 45-46). PYD programs hold promise in reducing the demand for treatment services, reducing societal costs.

\section{State policy: Two action steps}

While more and better data is needed, the work to date suggests that if PYD programs and strategies were to take deeper root and every young person had access to high-quality opportunities,

\section{We need to build a data-gathering infrastructure to ensure that state policy-making is well informed.}

many economic and social benefits could accrue to society. The research we have reviewed suggests two important foundational action steps toward building a state policy infrastructure that promotes youth development.

Data gathering. First, we need to build a data-gathering infrastructure to ensure that state policy-making is well informed. For example, we need to strengthen local administration of the California Healthy Kids Survey (CHKS), the only routinely collected source of data about youth development in California. The move to a statewide sampling strategy has eliminated capacity to generate localized assessments of youth well-being and access to support. Conversely, protecting and further developing CHKS, and linking it to broader individual tracking of student data, would enable even more robust analyses. The state might also invest in Youth Impact Assessments (a way of tracking the impact of various policies on youth outcomes), perhaps as part of broader Health Impact Assessments, to conduct as part of a community vitality strategy (Schmidt and Coffey 2010).

A key part of the data-gathering infrastructure is evaluation capacity building, to ensure that state investments are targeted to high-quality programs and services. California is promoting youth development in school, after-school and nonschool settings through a variety of current or pending state programs: which many communities are beginning

\section{Putting youth on the map}

Californians want - and need — the state's youth to thrive, not merely survive or face fewer problems. But how to tell whether our young people are doing well? To answer this question the Center for Regional Change and UC Cooperative Extension are partnering to create and disseminate a Youth Well-Being Index.

The index provides scores ranging from $0 \%$ to $100 \%$ for study areas across the state that are defined by the boundaries of California school districts. The scores take into account measures of teenagers' physical and emotional health, educational outcomes, social relationships and community contexts. The composite scores and associated data are reported in a series of color-coded maps.

Another measure, the Youth Vulnerability Index (with associated maps), identifies places where young people might suffer from a lack of support for their well-being. This index measures the relative rates at which youth in each California census tract experience conditions that are associated with inadequate support: school dropout/push-out rates, foster care referral, teen pregnancy and very low household income.

Indices, maps, downloadable data and links to other relevant data sources are available online at www.pyom.ucdavis.edu.

The website features a recorded webinar that gives an overview of the analysis behind the indices, information on navigating the site and ideas about how to use these resources. 


\section{4-H Thrive in California}

4-H Thrive is a research-based PYD program developed in partnership with the Thrive Foundation for Youth of Menlo Park, California. The program helps youth

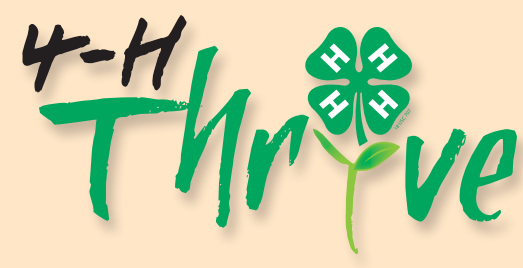

- Understand their spark, their inner source of motivation.

- Adopt a mind-set that is oriented toward learning and growth.

- Effectively set goals and work systematically toward their achievement.

- Practice self-reflection on personal growth and learning.

Researchers are conducting an extensive, rigorous evaluation of Thrive's effectiveness during the program rollout. To date, they have developed educational materials for a Leadership Project, which is provided free to participating junior and teen leaders. Master trainers (a statewide team of 209 specially trained youth and adults) are working in their communities, training local volunteers in how to teach youth the skills that will help them to thrive. Pilot evaluation data have been gathered from 4-H youth statewide through the new 4-H Online Record Book, as well as from master trainers and other volunteers. In addition, four counties will participate in a more in-depth evaluation.

Future research and extension activities will include the development of introductory leadership projects for primary members and pre-teen members, development of educational materials for the introductory leadership projects, and a randomized, controlled trial of 4-H Thrive in six counties.

\section{Research update: \\ Youth, social capital and vibrant communities}

Research on improvement of positive outcomes for young people typically focuses on the impact of one program. Comparatively few researchers have looked at the reciprocal relationship between support for young people and creation of vibrant, prosperous communities. A UC ANR team led by Richard Enfield and Keith Nathaniel is investigating whether the creation of social capital within a 4-H program also creates social capital within the larger community, and, if so, how that happens.

The research builds on an ongoing multistate project in which 4- $\mathrm{H}$ members use the community capitals (e.g., natural capital, fiscal capital, human capital) framework (Emery and Flora 2006; Emery et al. 2006) to map the local impact of their work. Data collected from diverse communities in 10 states led to some initial findings on characteristics of 4-H Youth Development Program experiences that link social capital development to civic engagement for youth. For example, researchers found that when you engage 4- $\mathrm{H}$ youth in activities that are important to non-4- $\mathrm{H}$ adults and to other community organizations, community members change their perception of the youth and are more ready to engage with them in civic activities.

The new research intends to revise and test key questions related to a young person's sense of agency within his or her community. The hypothesis postulates that community-oriented 4-H programs create more social capital, both for participants and for the community overall. This in turn may create additional capacity for youth and community betterment programs. The study hopes to identify how 4-H program practices and structures contribute to networking and the development of social capital. Results will be shared to inform youth development staff and volunteers as well as other researchers.
- State-funded after-school programs under Proposition 49 (The After School Education and Safety Program Act of 2002).

- The California Department of Education's Education and Safety Program.

- California Friday Night Live Partnership programs of the California Department of Public Health.

- Violence and gang prevention programs.

- Bullying prevention programs.

- School climate and safety programs.

Rigorous program evaluations are needed to determine the effectiveness of these programs. UC ANR, for example, is evaluating the implementation of $4-\mathrm{H}$ Thrive in after-school settings to gain new data on the program's efficacy and develop ways to strengthen it (see sidebar at left).

The list of intended outcomes that have been the focus of evaluations should be expanded. Education and risk behavior, which have been the primary concerns, have clear economic and policy implications, but other outcomes such as civic engagement and social capital are also pivotal in youth, community and broader U.S. societal well-being. As noted by Campbell and Erbstein (2012), “Young people are a powerful - if often untapped - resource in promoting community change that benefits children, youth and families."

Putnam's (2000) national survey found that states with high social capital — that is, where residents trust one another and join organizations and socialize with friends, and so on - are states where children are more likely to thrive. More research is needed to document the impact of these outcomes on individuals and society and to show how they can be improved through PYD programs. One such study, by UC ANR, is seeking evidence that investments in high-quality positive youth development programs might create higher levels of community social capital (see sidebar at lower left) (Emery and Flora 2006; Emery et al. 2006; Enfield and Owens 2009).

Measurable goals. Once a data-gathering infrastructure is in place, the state can begin to set measurable goals for youth outcomes, the second necessary action 
step. A national study estimates that only $9 \%$ of youth are currently receiving a high level of support for acquiring key developmental capacities, suggesting significant room for improvement in both the scope and quality of youth programming (Scales et al. 2011, 272). National data also shows that approximately $68 \%$ of youth are in some youth development program or youth activity, but only $35 \%$ of these programs and activities have high-quality features linked to the most positive outcomes (Scales et al. 2011, 274). It might be particularly useful to increase the overall percentage of youth who are constructively engaged as active participants in their own learning, both in and outside of school and ensure equitable outcomes across subpopulations and places.

In developing a state policy framework and particular policies, it will be useful to draw on the work of organizations such as the Forum for Youth Investment, which promotes information sharing among states and localities across the nation. While it hasn't been the focus of this article, their work and that of many other researchers suggests the need to look carefully at how our youth-serving institutions (schools, probation departments, hospitals and health-care providers, parks and recreation programs, social welfare, public housing, etc.) can align practices with PYD research, and how community and regional planning can facilitate all young people's access to developmentally supportive environments. Similar findings emerged in a Sacramento-region analysis of the relationship between youth well-being and regional vitality and sustainability (London and Erbstein 2011).

\section{Looking forward}

As we face the next two decades of transformational change, nurturing the healthy development of youth is critical to the future of the state and nation. Drawing from previously published peer-reviewed empirical research and literature reviews, our research points to two foundational steps needed to build state policies and infrastructure that promote youth development: improvement of data systems and setting broad youth policy goals at the state level. The need for positive pathways to adulthood is immediate and urgent, and critical to our future prosperity and democracy. As it has for the past century, UC Cooperative Extension's county-based 4-H Youth Development Program will continue to address this challenge by implementing programs at the cutting edge of youth development knowledge and practice.

D. Campbell is Community Studies Specialist, Department of Human Ecology, UC Davis; $K$. Trzesniewski is Associate Director of Research for the Statewide 4-H Youth Development Program and Associate Specialist in Cooperative Extension, Department of Human Ecology, UC Davis; K.C. Nathaniel is County Director and 4-H Youth Development Advisor, UCCE Los Angeles County; R.P. Enfield is County Director and 4-H Youth Development Advisor, UCCE San Luis Obispo County; and N. Erbstein is Assistant Research Scientist, Department of Human Ecology, UC Davis.

The authors would like to acknowledge the research assistance of Ramona Carlos, Katherine Heck and Aarti Subramaniam, on whose collective work we have drawn extensively.

\section{References}

Alberts AE, Chase P, Naudeau S, et al. 2006. Qualitative and quantitative assessments of thriving and contribu tion in early adolescence: Findings from the 4-H Study of Positive Youth Development. J Youth Dev 1(2):1-13.

Anderson SA, Sabatelli RM, Trachtenberg J. 2007. Community police and youth programs as a context for positive youth development. Police Quart 10(1):23-40 Beets MW, Flay BR, Vuchinich S, et al. 2009. Use of a social and character development program to prevent substance use, violent behaviors, and sexual activity among elementary school students in Hawaii. Am J Public Health 99(8):1438-45.

Belfield CR, Levin HM. 2007a. The Economic Losses from High School Dropouts in California. California Dropout Research Project, Report \#1. UC Santa Barbara. www. cdrp.ucsb.edu/pubs_reports.htm.

Belfield CR, Levin HM. 2007b. The Return on Investment for Improving California's High School Graduation Rate. California Dropout Research Project, Report \#2. UC Santa Barbara. www.cdrp.ucsb.edu/pubs_reports.htm.

Benard B. 1991. Fostering Resiliency in Kids: Protective Factors in the Family, School and Community. Northwest Regional Educational Laboratory, Western Center for Drug-Free Schools and Communities. Portland, OR. www. eric.ed.gov/PDFS/ED335781.pdf.

Benard B. 1993. Fostering resiliency in kids. Educ Leadership 51:44-8.

Benard B. 2004. Resiliency: What Have We Learned. San Francisco, CA: WestEd. www.wested.org/cs/we/view/ rs/712/.
Benner C, Rodriguez GM, Tithi B, Hartzog C. 2010. Cost of Dropouts in the Capital Region. Healthy Youth/Healthy Regions Working Paper. Center for Regional Change, UC Davis. http://regionalchange.ucdavis.edu/projects/completed-projects/hyhr_reports/CostOfDropouts_060911. pdf.

Benson PL. 1997. All Kids Are Our Kids: What Communities Must Do to Raise Caring and Responsible Children and Adolescents. San Francisco, CA: Jossey-Bass.

Benson PL, Leffert N, Scales PC, Blyth DA. 1998. Beyond the "village" rhetoric: Creating healthy communities for children and adolescents. Appl Dev Sci 2(3):138-59.

Benson PL, Pittman KJ. 2001. Moving the youth development message: Turning a vague idea into a moral imperative. In: Benson PL, Pittman KJ (eds.). Trends in Youth Development: Visions, Realities, and Challenges. Boston, MA: Kluwer Academic Publishers. p vii-xii.

Benson PL, Roehlkepartain EC, Rude SP. 2003. Spiritual development in childhood and adolescence: Toward a field of inquiry. Appl Dev Sci 7(3):205-13.

Benson PL, Scales PC. 2009. The definition and preliminary measurement of thriving in adolescence. J Posit Psychol 4(1):85-104

Benson PL, Scales PC, Hamilton SF, et al. 2006. Positive youth development so far: Core hypotheses and their implications for policy and practice. Search Inst Insights Evid 3(1):1-13. www.search-institute.org/research/Insights/InsightsEvidence-11-06.pdf.

Burciaga R, Erbstein N. 2010. Challenging Assumptions, Revealing Community Cultural Wealth: Young Adult Wisdom on Hope in Hardship. Healthy Youth/ Healthy Regions Working Paper. Center for Regional Change, UC Davis. http://regionalchange.ucdavis. edu/projects/completed-projects/hyhr_reports/ CommunityCulturalWealth_060811.pdf
Campbell D, Erbstein N. 2012. Engaging youth in community change: Three key implementation principles. Community Dev 43(1):63-79.

Catalano RF, Berglund ML, Ryan JAM, et al. 2004. Positive youth development in the United States: Research findings on evaluations of positive youth development programs. Ann Am Acad Polit SS 591:98-124.

Damon W. 2004. What is positive youth development? Ann Am Acad Polit SS 591(1):13-24.

Durlak JA, Taylor RD, Kawashima K, et al. 2007. Effects of positive youth development programs on school, family, and community systems. Am J Commun Psychol 39(34):269-86.

Durlak JA, Weissberg RP, Pachan M. 2010. A meta-analysis of after-school programs that seek to promote personal and social skills in children and adolescents. Am J Commun Psychol 45:294-309.

Emery M, Fey S, Flora C. 2006. Using community capitals to build assets for positive community change. CD Practice 13. www.comm-dev.org/

Emery M, Flora C. 2006. Spiraling-up: Mapping community transformation with the community capitals framework. Community Dev 37:19-35.

Enfield RP, Owens PE. 2009. Building and sustaining community-based youth development collaboratives. Community Dev 40(4):381-97.

Erbstein N. 2010. Toward Making Good on "All Youth": Engaging Underrepresented Youth Populations in Community Youth Development. REACH Issue Brief No. 6. Sierra Health Foundation. Sacramento, CA. http://ucanr. org/sites/UC_CCP/files/125989.pdf. 
Gambone MA, Yu HC, Lewis-Charp H. 2006. Youth organizing, identity-support, and youth development agencies as avenues for involvement. J Commun Practice 14(1):235-53

Gavin LE, Catalano RF, David-Ferdon C, et al. 2009. A review of positive youth development programs that promote adolescent sexual and reproductive health. J Adolescent Health 46(3, suppl 1):S75-91.

Geraghty E. 2010. Understanding Youth Health in the Capital Region. Healthy Youth/Healthy Regions Working Paper. Center for Regional Change, UC Davis. http://regionalchange.ucdavis.edu/ projects/completed-projects/hyhr_reports/ UnderstandingYouthHealth_060811.pdf.

Ginwright S, Cammarota J. 2007. Youth activism in the urban community: Learning critical civic praxis within community organizations. Int J Qual Stud Educ 20(6):693-710.

Ginwright S, James T. 2002. From assets to agents of change: Social justice, organizing and youth development. New Dir Youth Dev 96:27-46.

Ginwright S, Noguera P, Cammarota J (eds.). 2006. Beyond Resistance! Youth Activism and Community Change. New York: Taylor and Francis Group.

Gloppen KM, David-Ferdon C, Bates J. 2010. Confidence as a predictor of sexual and reproductive health outcomes for youth. J Adolescent Health 46(3, suppl 1): $542-58$

Goldschmidt P, Huang D, Chinen M. 2007. The Long-Term Effects of After-School Programming on Educational Adjustment and Juvenile Crime: A Study of LA's BEST After-School Program. National Center for Research on Evaluation, Standards, and Student Testing (CRESST). UC Los Angeles. www.lasbest.org/what/publications/LASBEST_DOJ_Final\%20Report.pdf.

Gomez BJ, Ang PMM. 2007. Promoting positive youth development in schools. Theor Pract 46(2):97-104. Grossman JB, Lind C, Hayes C, et al. 2009. The Cost of Quality Out-of-School-Time Programs. Public/Private Ven tures. Philadelphia, PA. www.ppv.org/ppv/publications/ assets/275 publication.pdf.

Guest A, Sneider B. 2003. Adolescents' extracurricular participation in context: The mediating effects of schools, communities, and identity. Sociol Educ 76(6):89-109.

Hamilton SF. 1999. A three-part definition of youth development. Unpublished ms. Cornell University School of Human Ecology, Ithaca, NY.

Hawkins JD, Oesterle S, Brown EC, et al. 2009. Results of a Type 2 translational research trial to prevent adolescent drug use and delinquency: A test of Communities That Care. Arch Pediat Adol Med 163(9):789-98.

Heck KE, Subramaniam A. 2009. Youth Development Frameworks. 4-H Center for Youth Development Mono graph. UC Davis. www.ca4h.org/files/29164.pdf.

Heck KE, Subramaniam A, Carlos R. 2010. The Step-It-Up2-Thrive Theory of Change. 4-H Center for Youth Development Monograph. UC Davis. www.thrivefoundation. org/Thrive\%20Monograph\%202010.pdf.

Hendricks PA. 1996. Targeting Life Skills Model. lowa State University Extension. Ames, IA. www.extension.iastate. edu/4h/explore/lifeskills.htm.

Hensley ST, Place NT, Jordan JC, Israel GD. 2007. Quality 4-H youth development program: Belonging. J Extension 45(5). www.joe.org/joe/2007october/a8.php.

Huang D, Dietel R. 2011. Making Afterschool Programs Better. Policy Brief No. 11. National Center for Research on Evaluation, Standards, and Student Testing (CRESST). UC Los Angeles. www.cse.ucla.edu/products/policy/ huang_MAPB_v5.pdf.

Hughes DM, Curnan SP. 2000. Community youth development: A framework for action. Community Youth Dev J 1(1):7-11.
Irby M, Ferber T, Pittman K, et al. 2001. Youth Action: Youth Contributing to Communities, Communities Supporting Youth. The Forum for Youth Investment, International Youth Foundation. Takoma Park, MD. www. forumfyi.org/files/YouthAction.pdf.

Jackson CF. 2009. Chicana and Chicano Art: ProtestArte. Tucson, AZ: University of Arizona Press.

Kress C. 2003. The circle of courage in practice: The 4-H Club study. Reclaim Child Youth 12(1):27.

Lamming J, Lemp C, Campbell D, et al. 2006. The Workforce Investment Act and California Youth: Implementing Local Youth Councils and Youth Programs. Fourth Interim Report, Evaluation of California's Workforce Development System. California Communities Program, UC Davis, Department of Human and Community Development. http://ucanr.org/sites/UC_CCP/files/125928.pdf.

Larson RW. 2000. Toward a theory of positive youth development. Am Psychol 35(1):170-83.

Lerner RM. 1995. American Youth in Crisis. Thousand Oaks, CA: Sage Publications.

Lerner RM, Benson PL (eds.). 2003. Developmental Assets and Asset-Building Communities: Implications for Research, Policy, and Practice. Boston, MA: Kluwer Academic Publishers.

Lerner RM, Fisher CB, Weinberg RA. 2000. Toward a science for and of the people: Promoting civil society through the application of developmental science. Child Dev 71(1):11-20.

Lerner RM, Lerner JV, Lewin-Bizan S, et al. 2011. Positive youth development: Processes, programs, and problematics. J Youth Dev 6(3):40-65.

Lerner RM, Lerner JV, Phelps E, et al. 2008. The Positive Development of Youth. The 4-H Study of Positive Youth Development: Report of the Findings from the First Four Waves of Data Collection: 2002-2006. Tufts University. Medford, MA

London J, Erbstein N, et al. 2011. Healthy Youth/Healthy Regions: Informing Action for the Nine-County Capital Region and Its Youth. Center for Regional Change, UC Davis.

Masten AS, Best KM, Garmezy N. 1990. Resilience and development: Contributions from the study of children who overcome adversity. Dev Psychopathol 2:425-44.

Meltzer IJ, Fitzgibbon JJ, Leahy PJ, Petsko KE. 2006. Youth development program: Lasting impact. Clin Pediatr 45(7):655-60.

[NRC/IOM] National Research Council and Institute of Medicine 2002 Community Programs to Promote Youth Development. Washington, DC: National Academies Press.

Oman RF, Vesely SK, McLeroy KR, et al. 2002. Reliability and validity of the Youth Asset Survey (YAS). J Adolescent Health 31(3):247-55.

Peterson B, Gerhard G, Hunter K, et al. 2001. Prepared and Engaged Youth Serve American Communities: The National 4-H Assessment Project National 4-H Headquarters. Washington, DC: www.ca4h.org/files/13698.pdf.

Phelps E, Zimmerman S, Warren AEA, et al. 2009. The structure and developmental course of positive youth development (PYD) in early adolescence: Implications fo theory and practice. J Appl Dev Psychol 30(5):571-84.

Pittman KJ. 1991. Promoting Youth Development: Strengthening the Role of Youth Serving and Community Organizations. Center for Youth Development and Policy Research, Academy for Educational Development. Washington, DC. www.servicelearning.org/library/ resource/3350.

Pittman KJ. 2000. Balancing the equation: Communities supporting youth, youth supporting communities. Community Youth Dev J 1:33-6.

Pittman KJ, Irby M, Ferber T. 2000. Unfinished business: Further reflections on a decade of promising youth development. The Forum for Youth Investment. Takoma Park, MD. www.ppv.org/ppv/publications/assets/74_sup/ ydv_1.pdf.
Putnam RD. 2000. Bowling Alone: The Collapse and Revival of American Community. New York: Simon and Schuster.

Romero M, London J, Erbstein N. 2010. Opportunities and Challenges for Youth Civic Engagement. Healthy Youth/ Healthy Regions Working Paper. Center for Regional Change, UC Davis. http://regionalchange.ucdavis.edu/ projects/completed-projects/hyhr_reports/ES_YouthCivicEngagement_062111.pdf.

Roth JL, Brooks-Gunn J. 2003. Youth development programs: Risk, prevention and policy. J Adolescent Health 32:170-82.

Russell ST, Van Campen K. 2011. Diversity and inclusion in youth development: What we can learn from marginalized young people. J Youth Dev 6(3):95-108.

Scales P, Benson P, Leffert N, Blyth DA. 2000. Contribution of developmental assets to the prediction of thriving among adolescents. Appl Dev Sci 4(1):27-46.

Scales PD, Benson PL, Roehlkepartain EC. 2011. Adolescent thriving: The role of sparks, relationships, and empowerment. J Youth Adolescence 40:263-77.

Schmidt M, Coffey J. 2010. Change in sight: Child wellbeing as a policy development framework. In: Big Ideas: Game-Changers for Children. Washington DC: First Focus. www.firstfocus.net/library/reports/change-in-sight-childwell-being-as-a-policy-development-framework.

Sieving RE, Bernat DH, Resnick MD, et al. 2011. A clinic based youth development program to reduce sexual risk behaviors among adolescent girls: Prime Time pilot study. Health Promot Practice 12(3)

Smith C, Akiva T, Sugar S, et al. 2012. Continuous Quality Improvement in Afterschool Settings: Impact Finding from the Youth Program Quality Intervention Study. The Forum for Youth Investment. Washington, DC. www. cypq.org/sites/cypq.org/files/publications/YPQI\%20 Study\%20Full\%20Report.pdf.

Stanton-Salazar RD. 2011. A social capital framework for the study of institutional agents and their role in the empowerment of low-status students and youth. Youth Soc 43(3):1066-109.

Sum A. 2003. Leaving Young Workers Behind. Nationa League of Cities, Institute for Youth, Education, and Families.

Taylor L, Rumberger RW. 2010. A More Accurate Measure of California's Dropout Rate Statistical Brief 13. California Dropout Research Project. UC Santa Barbara. http:// toped.svefoundation.org/wp-content/uploads/2010/12/ Dropouts-method-Rumberger120810.pdf.

Taylor-Powell E, Calvert M. 2006. Wisconsin 4-H Youth Development Arts and Communication Program Evalu ation. Final report. University of Wisconsin Extension. Madison. www.uwex.edu/ces/pdande/evaluation/pdf/ AC-finalreport.pdf

Tebes JK, Feinn R, Vanderploeg JJ, et al. 2007. Impact of a positive youth development program in urban afterschool settings on the prevention of adolescent substance use. J Adolescent Health 41(3):219-20.

Theokas C, Almerigi JB, Lerner RM, et al. 2005. Conceptualizing and modeling individual and ecological components of thriving in early adolescence. J Early Adolescence 25(1):113-43.

Thrive Foundation for Youth. 2010. Step-It-Up-2-Thrive Theory of Change. www.thrivefoundation.org/stepitup. html.

Weissberg RP, Utne O'Brien M. 2004. What works in school-based social and emotional learning programs for positive youth development. Ann Am Acad Polit SS 591:86-97.

Yohalem N, Wilson-Ahlstrom A, Fischer S, Shinn M. 2009 Measuring Youth Program Quality: A Guide to Assessment Tools (2nd ed.). The Forum for Youth Investment. Washington, DC. www.forumfyi.org/files/Measuring Yout hProgramQuality_2ndEd.pdf.

Yosso TJ. 2005. Whose culture has capital? A critical race theory discussion of community cultural wealth. Race Ethn Educ 8(1):69-91. 